\title{
ANALISIS SENTIMEN MENGGUNAKAN METODE NAÏVE BAYES CLASSIFIER DENGAN SELEKSI FITUR CHI SQUARE
}

\author{
Juen Ling ${ }^{1}$, I Putu Eka N. Kencana ${ }^{\S 2}$, Tjokorda Bagus Oka ${ }^{3}$ \\ ${ }^{1}$ Jurusan Matematika, Fakultas MIPA - Universitas Udayana [Email: juenling260292@gmail.com] \\ ${ }^{2}$ Jurusan Matematika, Fakultas MIPA - Universitas Udayana [Email: i.putu.enk@gmail.com] \\ ${ }^{3}$ Jurusan Matematika, Fakultas MIPA - Universitas Udayana [Email: tjokordabagusoka@ gmail.com] \\ ${ }^{\S}$ Corresponding Author
}

\begin{abstract}
Sentiment analysis is the computational study of opinions, sentiments, and emotions expressed in texts. The basic task of sentiment analysis is to classify the polarity of the existing texts in documents, sentences, or opinions. Polarity has meaning if there is text in the document, sentence, or the opinion has a positive or negative aspect. In this study, classification of the polarity in sentiment analysis using machine learning techniques, that is Nä̈ve Bayes classifier. Criteria for text classification decisions, learned automatically from learning the data. The need for manual classification is still required because training the data derived from manually labeling, the label (feature) refers to the process of adding a description of each data according to its category. In the process of labeling, feature selection is used and performed by chi-square feature selection, to reduce the disturbance (noise) in the classification. The results showed that the frequency of occurrences of the expected features in the true category and in the false category have an important role in the chi-square feature selection. Then classification by Naïve Bayes classifier obtained an accuracy of $83 \%$ and a harmonic average of $90.713 \%$.
\end{abstract}

Keywords: chi square, classification, feature selection, machine learning technique, Nä̈ve Bayes, sentiment analysis.

\section{PENDAHULUAN}

Informasi dalam bentuk teks adalah informasi yang penting dan banyak didapatkan dari berbagai sumber seperti buku, surat kabar, situs web, ataupun pesan e-mail. Teks merupakan sebuah hamparan bahasa, baik dalam pembicaraan ataupun dalam tulisan, yang memiliki makna, bersifat praktis dan berguna untuk umum serta berhubungan dengan dunia nyata (Bolshakov \& Gelbukh [2]). Sebuah teks dapat terdiri dari hanya satu kata ataupun susunan kalimat (Carter \& McCarthy [3]). Pengambilan informasi dari teks (text mining) antara lain dapat meliputi kategorisasi teks atau dokumen, analisis sentimen (sentiment analysis), pencarian topik yang lebih spesifik (search engine), serta spam filtering. Gagasan umum text mining adalah untuk mengetahui cakupan atau topik dari permasalahan dalam teks (Maning, et al. [6]). Text mining penting dalam analisis sentimen sebagai pengidentifikasi emosional suatu pernyataan, sehingga banyak studi tentang analisis sentimen dilakukan (Zhang, et al. [12]).

Analisis sentimen adalah studi komputasi dari opini-opini, sentimen, serta emosi yang diekspresikan dalam teks (Liu [5]). Tugas dasar dalam analisis sentimen adalah mengelompokkan polaritas dari teks yang ada dalam dokumen, kalimat, atau pendapat. Polaritas mempunyai arti apakah teks yang ada dalam dokumen, kalimat, atau pendapat memiliki aspek positif atau negatif. Salah satu 
teknik pembelajaran mesin untuk analisis sentimen adalah Nä̈ve Bayes classifier (NBC). NBC merupakan teknik pembelajaran mesin yang berbasis probabilistik. NBC adalah metode sederhana tetapi memiliki akurasi serta performansi yang tinggi dalam pengklasifikasian teks (Routray, et al. [9]).

Banyak ide telah muncul selama beberapa tahun belakangan tentang teknik pembelajaran mesin untuk permasalahan analisis sentimen. Xhemali, et al. [11] berkonsentrasi pada perbandingan tiga metode. Metode-metode tersebut adalah Naïve Bayes, Pohon Keputusan, dan Neural Networks. Hasil penelitian secara keseluruhan menunjukkan bahwa Naïve Bayes classifier adalah pilihan terbaik untuk pelatihan domain. Metode berbasis leksikon untuk melakukan analisis sentimen pertama kali diterapkan oleh Zhang et al. [12]. Metode ini dapat memberikan presisi yang tinggi tapi recall yang rendah. Penelitian lain yang dilakukan Taboada, et al. [10] yang menerapkan pendekatan berbasis leksikon untuk mengekstrak sentimen dari teks yang menggunakan kamus kata-kata atau frase dijelaskan dengan orientasi semantik meliputi polaritas dan strength dari kata-kata, serta menggabungkan intensifikasi dan negasi. Routray et al. [9] dan Khairnar \& Kinikar [4] membahas banyak pendekatan dari para peneliti yang berbeda, serta menyatakan bahwa metode pembelajaran mesin menjadi cara yang efisien untuk menganalisis sentimen.

Penggabungan yang dilakukan dalam tulisan ini adalah menggabungkan NBC dengan seleksi fitur. Penyeleksian fitur diperlukan dalam proses memilih subset dari fitur-fitur yang relevan untuk digunakan dalam konstruksi model probabilistik NBC. Penyeleksian fitur yang digunakan adalah seleksi fitur chi square. Dari data yang tersedia, sejumlah data akan digunakan untuk menguji hasil klasifikasi sistem NBC dengan penyeleksian fitur chi square.

\section{KAJIAN PUSTAKA}

\subsection{Pre-Processing}

Tokenization adalah tugas pemotongan urutan karakter dan sebuah set dokumen yang diberikan menjadi potongan-potongan kata atau karakter yang sesuai dengan kebutuhan sistem. Potongan-potongan tersebut dikenal dengan istilah token (Maning, et al. [6]).

Stemming merupakan salah satu proses dari mengubah token yang berimbuhan menjadi kata dasar, dengan menghilangkan semua imbuhan yang ada pada token tersebut. Pentingnya stemming dalam proses pembuatan sistem adalah untuk menghilangkan imbuhan pada awalan dan akhiran. Berdasarkan hasil proses tersebut, akan didapatkan sebuah informasi mengenai banyaknya fitur yang muncul dalam sebuah dokumen.

Stopwords dapat diartikan sebagai menghilangkan karakter, tanda baca, serta kata-kata umum yang tidak memiliki makna atau informasi yang dibutuhkan. Stopwords umumnya digunakan dalam pengambilan informasi salah satu contohnya adalah mesin pencari Google. Pengurangan ukuran indeks dalam teks dengan penghilangan beberapa kata kerja, kata sifat, dan kata keterangan lainnya dapat dimasukkan ke dalam daftar stopwords.

\subsection{Seleksi Fitur Chi Square}

Seleksi fitur dilakukan untuk mereduksi fitur-fitur yang tidak relevan dalam proses klasifikasi oleh NBC. Terdapat beberapa metode untuk penyeleksian fitur yaitu Mutual Information (MI), chi square $\left(\chi^{2}\right)$, dan yang umum digunakan adalah frequency-based. Seleksi fitur frequency-based menggunakan jumlah kemunculan term atau frekuensi term yang diurutkan dari yang paling banyak sampai paling sedikit dan diambil beberapa urutan atas untuk digunakan sebagai fitur. Seleksi fitur MI merupakan ukuran yang mengukur kehadiran atau ketidakhadiran sebuah term yang memberikan kontribusi kepada kategori yang tepat. Sedangkan seleksi 
fitur Chi Square menggunakan teori statistika untuk menguji independensi sebuah term dengan kategorinya. Salah satu tujuan penggunaan seleksi fitur adalah untuk menghilangkan fitur pengganggu dalam klasifikasi.

Dalam seleksi fitur Chi Square berdasarkan teori statistika, dua peristiwa di antaranya adalah, kemunculan dari fitur dan kemunculan dari kategori, yang kemudian setiap nilai term diurutkan dari yang tertinggi berdasarkan perhitungan berikut [6]:

$$
X^{2}(D, t, c)=\sum_{e_{t} \in\{0,1\}} \sum_{e_{c} \in\{0,1\}} \frac{\left(N_{e_{t} e_{c}}-E_{e_{e} e_{c}}\right)^{2}}{E_{e_{t} e_{c}}}
$$

Penyeleksian fitur Chi Square dilakukan dengan cara mengurutkan setiap fitur berdasarkan hasil seleksi fitur Chi Square dari nilai yang terbesar hingga nilai yang terkecil. Nilai seleksi fitur Chi Square yang lebih besar dari nilai signifikan menunjukkan penolakan hipotesis independensi. Sedangkan jika dua peristiwa menunjukkan dependen, maka fitur tersebut menyerupai atau sama dengan label kategori yang sesuai pada kategori.

\subsection{Naïve Bayes Classifier}

Naïve Bayes classifier merupakan suatu metode klasifikasi yang menggunakan perhitungan probabilitas. Konsep dasar yang digunakan pada Naïve Bayes classifier adalah Teorema Bayes yang dinyatakan pertama kali oleh Thomas Bayes [1]. Nilai probabilitas yang digunakan dinyatakan secara sederhana sebagai berikut (Pop [8]):

$$
p(C \mid D)=\frac{p(D \mid C) p(C)}{p(D)} .
$$

\subsection{Evaluasi Kinerja}

Dua dasar ukuran yang sering digunakan untuk mengetahui efektivitas sistem adalah precision atau presisi dan recall. Presisi $(P)$ adalah ukuran banyaknya dokumen yang ditemukan relevan, dinyatakan dalam pecahan sebagai berikut;

$$
\text { Precision }=\frac{\#(\text { Relevant item retrieved })}{\#(\text { Retrieved } \text { item })}
$$

sedangkan recall $(R)$ adalah ukuran banyaknya dokumen yang relevan dapat ditemukan kembali, dinyatakan dalam pecahan sebagai berikut;

$$
\text { Recall }=\frac{\#(\text { Relevant } \text { item } \text { retrieved })}{\#(\text { Relevant } \text { item })}
$$

\section{METODE PENELITIAN}

Data pada penelitian ini berupa opini berbahasa Inggris tentang produk telepon genggam. Dari data yang tersedia, diambil secara acak sebanyak 200 buah opini yang terdiri dari 100 buah opini positif dan 100 buah opini negatif. Data tersebut digunakan sebagai data pembelajaran mesin dan data uji untuk mengevaluasi kinerja sistem.

Adapun langkah-langkah untuk perancangan analisis sentimen yang dibahas adalah sebagai berikut:

1. Tahap pre-processing data

Pada tahap pre-processing data, awal mula data mentah dilakukan proses tokenizer, stemming, serta stopwords. Hasil dari tahapan ini menghasilkan fitur yang digunakan sebagai data pembelajaran mesin oleh NBC.

2. Tahap penyeleksian fitur dengan seleksi fitur Chi Square

Penelitian ini menggunakan seleksi fitur Chi Square. Langkah awal, yaitu menentukan tabel kontingensi masing-masing fitur dengan Tabel 1. Langkah selanjutnya menghitung nilai seleksi fitur Chi Square dengan persamaan berikut (Maning, et al. [6]):

$$
X^{2}(D, t, c)=\frac{\left(N_{00}+N_{11}+N_{10}+N_{01}\right) \times\left(N_{00} N_{11}-N_{10} N_{01}\right)^{2}}{\left(N_{11}+N_{01}\right) \times\left(N_{11}+N_{10}\right) \times\left(N_{10}+N_{00}\right) \times\left(N_{01}+N_{00}\right)} .
$$

Seleksi fitur Chi Square digunakan untuk pegamatan kebersesuaian (goodness of fit) dari kategori dengan terms. Uji Chi Square dalam statistika diterapkan untuk menguji independensi dari dua peristiwa. Sedangkan 
dalam seleksi fitur berdasarkan teori statistika, dua peristiwa tersebut di antaranya adalah, kemunculan dari fitur dan kemunculan dari kategori.

\section{Tabel 1. Tabel Kontingensi Seleksi Fitur Chi}

Square
\begin{tabular}{|l|l|l|}
\hline & $e_{c}=1$ & $e_{c}=0$ \\
\hline$e_{t}=1$ & $N_{11}$ & $N_{10}$ \\
\hline$e_{t}=0$ & $N_{01}$ & $N_{00}$ \\
\hline
\end{tabular}

Langkah terakhir yaitu mengurutkan semua hasil perhitungan seleksi fitur dari yang terbesar sampai yang terkecil. Penghapusan fitur dilakukan jika penerimaan hipotesis independen terpenuhi.

\section{Tahap klasifikasi data}

Naïve Bayes menganggap sebuah dokumen sebagai kumpulan dari kata yang menyusun dokumen tersebut. Naïve Bayes juga tidak memperhatikan urutan kemunculan kata pada dokumen. Adapun algoritma NBC [7] untuk klasifikasi data dapat dilihat pada Gambar 1.

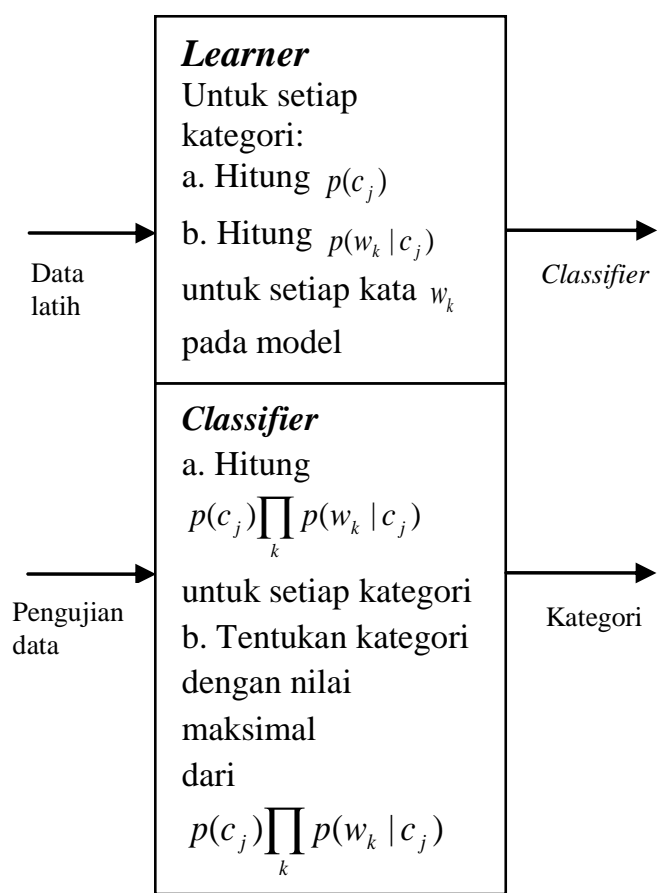

Gambar 1. Proses Klasifikasi dengan NBC
4. Tahap evaluasi kinerja sistem

Pada tahap evaluasi sistem, perhitungan menggunakan tabel kontingensi yang diberikan pada Tabel 2.

Tabel 2. Tabel Kontingensi Evaluasi Kinerja Sistem

\begin{tabular}{|c|c|c|}
\hline \# & Relevant & Not Relevant \\
\hline Retrieved & $\begin{array}{c}\text { True positive } \\
(T P)\end{array}$ & $\begin{array}{c}\text { False } \\
\text { Positive (FP) }\end{array}$ \\
\hline $\begin{array}{c}\text { Not } \\
\text { Retrieved }\end{array}$ & $\begin{array}{l}\text { False negative } \\
\qquad(F N)\end{array}$ & $\begin{array}{c}\text { True } \\
\text { Negative } \\
\text { (TN) }\end{array}$ \\
\hline
\end{tabular}

Alternatif yang jelas terlintas pada pikiran pembaca dalam menilai sebuah sistem adalah dengan akurasi. Akurasi adalah ketepatan suatu sistem melakukan klasifikasi yang benar. Perhitungan untuk Presisi $(P)$, Recall $(R)$, dan akurasi dapat dikalkulasi sebagai berikut:

$$
\begin{aligned}
& P=\frac{T P}{T P+F P} \\
& R=\frac{T P}{T P+F N} ;
\end{aligned}
$$

$$
\text { Akurasi }=\frac{T P+T N}{T P+F P+F N+T N} .
$$

Sebuah ukuran yang digunakan sebagai rata-rata terbobot harmonik dari $P$ dan $R$ adalah sebagai berikut:

$$
F_{1}=\frac{2 P R}{P+R}
$$

\section{HASIL DAN PEMBAHASAN}

Penggunaan data sebanyak 200 buah opini tentang opini berbahasa Inggris pengguna telepon genggam yang terbagi atas 100 buah opini positif dan 100 buah opini negatif. Sebagai data latih digunakan sejumlah 100 buah data yaitu data yang terbagi masingmasing 50 buah opini positif dan 50 buah opini. 
Sisanya yaitu 100 buah opini yang terbagi sama rata antara opini positif dan opini negatif digunakan sebagai data uji.

Perancangan basis data dengan menggunakan XAMPP, memuat tiga buah tabel yang independen, yaitu tabel datatraining, corpus, tb_feature. Tabel datatraining memuat keseluruhan data latih mentah. Tabel tb_feature memuat fitur-fitur yang telah diberi label positif atau negatif secara manual. Sedangkan tabel corpus memuat fitur-fitur yang telah diseleksi melalui tahapan yang telah diuraikan pada implementasi seleksi fitur Chi Square. Pada sistem, proses-proses atau urutan proses dirancang untuk mengklasifikasi data uji dengan melalui beberapa tahapan. Tahapan tersebut merupakan tahapan yang telah diuraikan pada tahap pre-processing dan implementasi Naïve Bayes classifier.

Langkah awal yaitu melakukan pelabelan secara manual dari 100 buah data latih. Pada pelabelan fitur tersebut dilakukan proses stemming. Pelabelan tersebut menghasilkan 117 fitur diantaranya 66 fitur negatif dan 51 fitur positif.

Setelah melakukan pelabelan dilanjutkan dengan proses penyeleksian fitur. Seleksi fitur dilakukan dari sebanyak 117 fitur yang diperoleh dari pelabelan. Pada tahap seleksi fitur ada tiga metode yang diketahui, yaitu Mutual Information (MI), chi square $\left(\chi^{2}\right)$, dan frequency-based. Seleksi fitur frequency-based menggunakan jumlah kemunculan term atau frekuensi term yang diurutkan dari yang paling banyak sampai paling sedikit dan diambil beberapa urutan atas untuk digunakan sebagai fitur.

Metode seleksi fitur Frequency-based memilih fitur yang paling umum di kategori. Metode seleksi fitur Frequency-based dapat didefinisikan baik sebagai frekuensi dokumen (jumlah dokumen di kategori $c$ yang mengandung fitur $t$ ) atau sebagai koleksi frekuensi (jumlah token dari $t$ yang muncul pada dokumen dalam $c$ ). Seleksi fitur MI merupakan ukuran yang mengukur kehadiran atau ketidakhadiran sebuah term yang memberikan kontribusi kepada kategori yang tepat. Sedangkan seleksi fitur Chi Square menggunakan teori statistika untuk menguji independensi sebuah term dengan kategorinya. Salah satu tujuan penggunaan seleksi fitur adalah untuk menghilangkan fitur pengganggu dalam klasifikasi. Maning, et al. [6] mengatakan untuk kasus seleksi fitur frequency-based memiliki kinerja yang buruk dibandingkan MI dan Chi Square.

Perbandingan dari peningkatan akurasi dapat diamati pada Gambar 2, dengan $\boldsymbol{F}_{\text {1-measure }}$ merupakan ukuran ketepatan klasifikasi oleh metode Naïve Bayes Classifier dengan dilakukannya beberapa metode seleksi fitur yaitu MI, Chi Square dan frequency-based. Pada Gambar 2, saat 100 buah fitur terpilih, ketepatan klasifikasi oleh metode seleksi fitur frequency-based memperoleh di bawah $40 \%$, metode seleksi fitur $M I$ memperoleh hasil di atas $60 \%$, dan metode seleksi fitur chi square memperoleh hasil yang mendekati $60 \%$ [6]. Hal ini menunjukkan bahwa metode frequencybased tidak seharusnya digunakan.

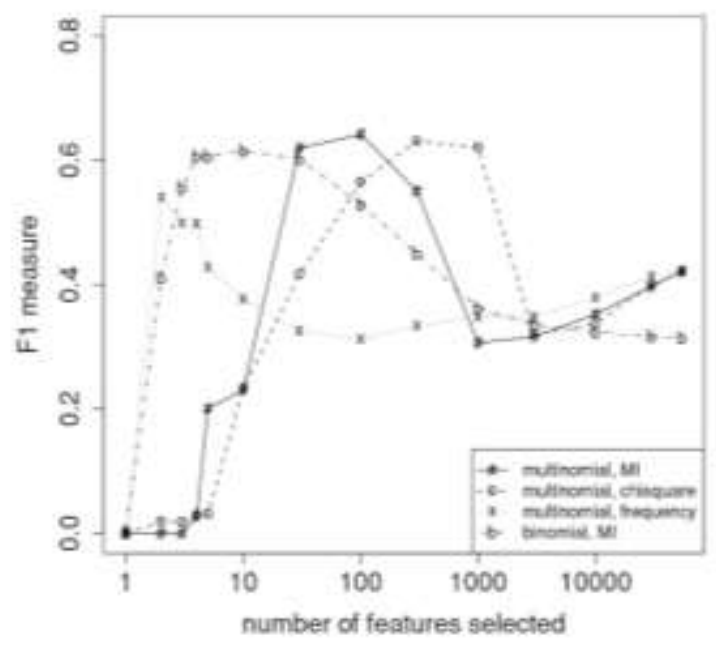

Gambar 2. Perbandingan Metode Seleksi Fitur dalam Ketepatan Klasifikasi

Hipotesis awal menyatakan bahwa term $t$ independen terhadap kategori $c$. Sedangkan hipotesis akhir menyatakan bahwa term $t$ dependen terhadap kategori $c$. Hasil seleksi fitur Chi Square dari 117 fitur terseleksi menjadi 30 fitur yang terdiri dari 14 fitur 
negatif dan 16 fitur positif. Proses penyeleksian fitur sebanyak 117 fitur dengan seleksi fitur $C h i$ Square yang dibangun dengan bahasa pemrograman Java membutuhkan waktu komputasi hanya dua detik.

Diagram alir untuk merepresentasikan langkah-langkah sistem untuk melakukan proses penyeleksian fitur dengan seleksi fitur Chi Square dapat dilihat pada Gambar 3 berikut:

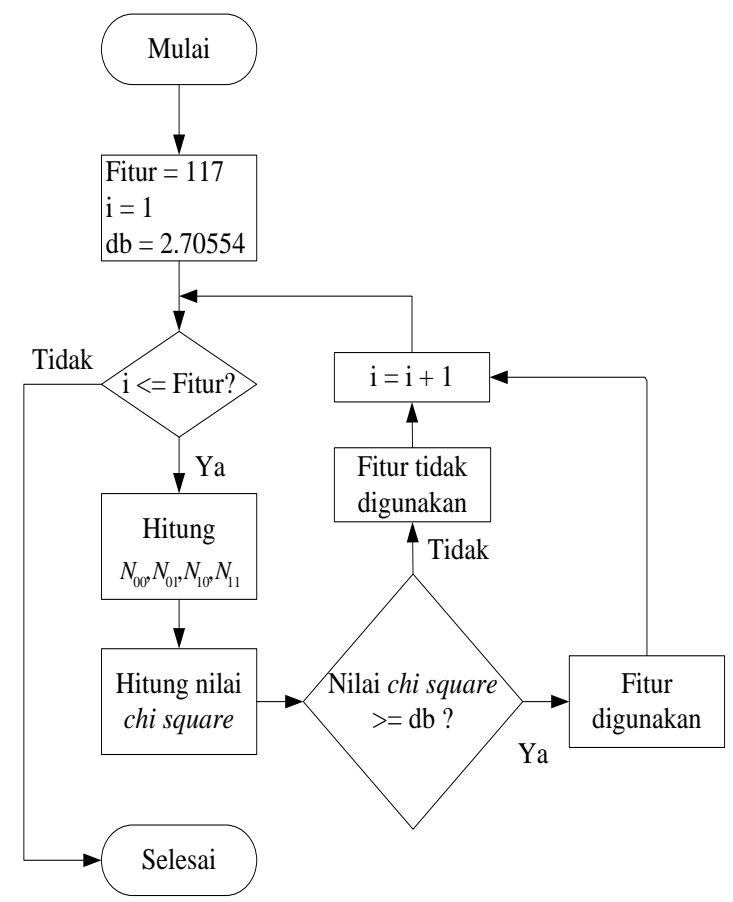

Gambar 3. Diagram Alir Penyeleksian Fitur dengan Chi Square

Dalam seleksi fitur Chi Square frekuensi pada fitur menjadi kurang penting bila fitur tersebut juga muncul beberapa kali pada kategori yang tidak diharapkan. Sehingga bila kedua metode tersebut dibandingkan seleksi fitur Chi Square akan lebih baik daripada frequency-based. Kemunculan frekuensi fitur pada kategori yang diharapkan dan kategori yang tidak diharapkan memiliki peranan penting dalam seleksi fitur Chi Square. Sedangkan pada frequency-based yang memiliki peranan penting hanya kemunculan frekuensi fitur pada kategori yang diharapkan. Apabila penolakan hipotesis awal terpenuhi atau penerimaan hipotesis akhir terpenuhi, fitur tersebut akan digunakan dalam proses klasifikasi NBC.

Mengacu pada konsep dasar Naïve Bayes classifier yaitu Teorema Bayes yang dinyatakan pertama kali oleh Thomas Bayes [1]:

$$
p(C \mid D)=\frac{p(D \mid C) p(C)}{p(D)} .
$$

Nilai probabilitas dihitung dari kemunculan opini yang setara dengan perkalian nilai probabilitas kemunculan fitur dalam opini tersebut. Adapun diagram alir untuk proses klasifikasi dengan NBC dapat dilihat pada Gambar 4.

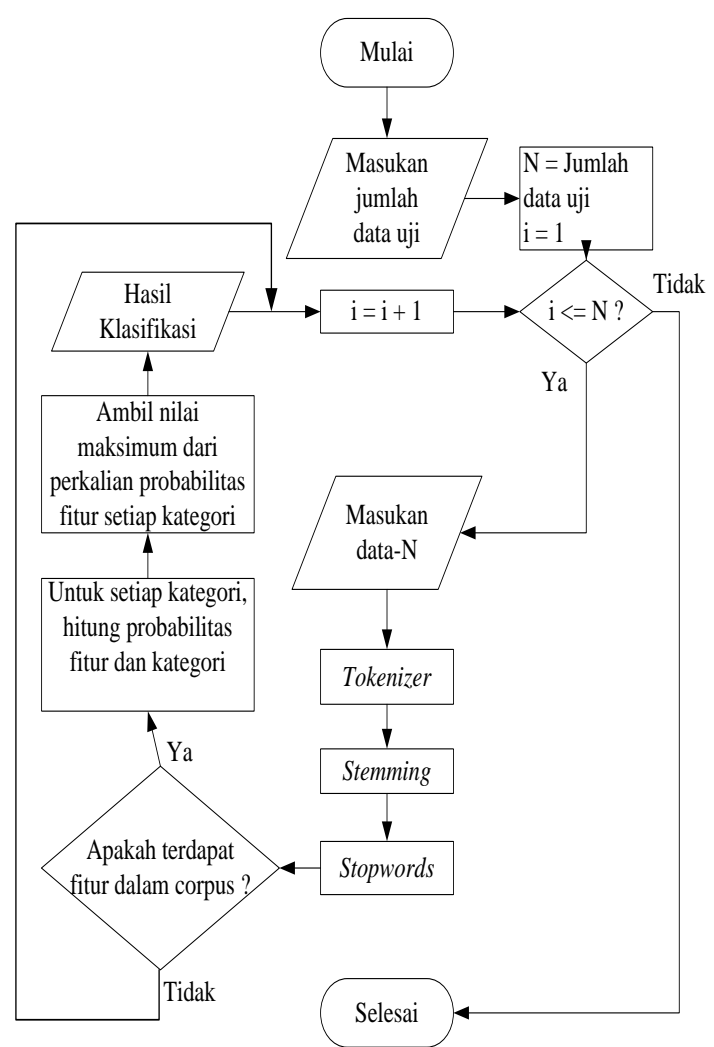

Gambar 4. Diagram Alir Proses Klasifikasi dengan NBC

Klasifikasi oleh NBC pada data uji negatif memperoleh ketepatan sebesar $72 \%$ sedangkan untuk data uji positif memperoleh $96 \%$. Secara keseluruhan data uji, klasifikasi oleh NBC 
memperoleh akurasi sebesar $83 \%$ dan rata-rata harmonik ( $\left.\boldsymbol{F}_{\text {measure }}\right)$ sebesar $90,713 \%$. Pada penelitian ini, NBC melakukan kesalahan klasifikasi sebanyak empat data uji, tidak dapat mengklasifikasi 13 data uji dari total keseluruhan 100 data uji.

NBC bekerja dengan baik dalam mengklasifikasi dan juga merupakan teknik pembelajaran mesin yang sederhana dengan hanya menggunakan kemunculan fitur serta frekuensi fitur pada tiap-tiap opini. Secara global klasifikasi oleh NBC dapat digunakan sebagai teknik analisis sentimen pasar produk seperti yang dilakukan pada penelitian ini.

Tabel 3. Peringkat Hasil Seleksi Fitur Chi

\begin{tabular}{|l|l|l|c|l|}
\hline No & \multicolumn{1}{|c|}{ Fitur } & Kategori & $\begin{array}{c}\text { Frekuensi } \\
\text { Fitur }\end{array}$ & Nilai chi square \\
\hline 1 & dissapoint & negatif & 29 & 40.84507042 \\
\hline 2 & great & positif & 26 & 35.13513514 \\
\hline 3 & love & positif & 22 & 28.20512821 \\
\hline 4 & recommend & positif & 16 & 15.94613749 \\
\hline 5 & good & positif & 16 & 15.94613749 \\
\hline 6 & us & negatif & 10 & 11.11111111 \\
\hline 7 & excel & positif & 10 & 11.11111111 \\
\hline 8 & amaz & positif & 8 & 8.695652174 \\
\hline 9 & perfect & positif & 8 & 8.695652174 \\
\hline 10 & easi & positif & 8 & 8.695652174 \\
\hline 11 & lot & positif & 10 & 8.273748723 \\
\hline 12 & return & negatif & 7 & 7.52688172 \\
\hline 13 & broken & negatif & 7 & 7.52688172 \\
\hline 14 & bad & negatif & 7 & 7.52688172 \\
\hline 15 & upset & negatif & 6 & 6.382978723 \\
\hline 16 & fix & negatif & 4 & 4.166666667 \\
\hline 17 & highli & positif & 4 & 4.166666667 \\
\hline 18 & best & positif & 4 & 4.166666667 \\
\hline 19 & awesom & positif & 4 & 4.166666667 \\
\hline 20 & pai & negatif & 3 & 3.092783505 \\
\hline 21 & poor & negatif & 3 & 3.092783505 \\
\hline 22 & cheat & negatif & 3 & 3.092783505 \\
\hline 23 & old & negatif & 3 & 3.092783505 \\
\hline 24 & damag & negatif & 3 & 3.092783505 \\
\hline 25 & over & sure & 3 & 3.092783505 \\
\hline
\end{tabular}

\begin{tabular}{|l|l|l|c|c|}
\hline 27 & beauti & positif & 3 & 3.092783505 \\
\hline 28 & like & positif & 10 & 2.990033223 \\
\hline 29 & unlock & negatif & 5 & 2.836879433 \\
\hline 30 & fast & positif & 5 & 2.836879433 \\
\hline
\end{tabular}

Daftar hasil perhitungan memuat nilai seleksi fitur Chi Square yang berdasarkan hipotesis independensi, dengan hipotesis awal menyatakan bahwa term $t$ independen terhadap kategori c. Apabila nilai seleksi fitur Chi Square lebih besar daripada nilai signifikan, sehingga penolakan hipotesis awal akan terpenuhi. Hipotesis akhir yang diperoleh menyatakan bahwa term $t$ dependen terhadap kategori $c$.

\section{SIMPULAN}

Berdasarkan hasil yang diperoleh dapat disimpulan bahwa kemunculan frekuensi fitur pada kategori yang diharapkan dan kategori yang tidak diharapkan memiliki peranan penting dalam seleksi fitur Chi Square, oleh karena itu seleksi fitur Chi Square baik digunakan dalam penyeleksian fitur dibandingkan dengan metode frequency-based. Serta pembangunan sistem analisis sentimen menggunakan metode NBC dengan bahasa pemrograman Java memperoleh akurasi sebesar $83 \%$ dan rata-rata harmonik sebesar $90,713 \%$. Terdapat kesalahan klasifikasi karena pada data uji terdapat fitur yang muncul pada bukan kategorinya. Untuk penelitian selanjutnya yaitu dapat dibandingkan hasil seleksi fitur dari chi square terhadap hasil seleksi fitur dari Mutual Information berdasarkan segi waktu komputasi dan segi ketepatan klasifikasi. Serta menggabungkan teknik pembelajaran mesin NBC dengan beberapa model $n$-gram untuk meneliti hasil ketepatan klasifikasi yang diperoleh.

\section{DAFTAR PUSTAKA}

[1] Aldrich, J., 2008. R. A. Fisher on Bayes and Bayes' Theorem. Bayesian Analysis, 3(1), pp. 161-170.

[2] Bolshakov, I. A. \& Gelbukh, A., 2004. Computational Linguistics. 1st ed. 
Mexico: Instituto Politécnico Nacional.

[3] Carter, R. \& McCarthy, M., 2006.

Cambridge Grammar of English.

Cambridge: Cambridge Univ. Press.

[4] Khairnar, J. \& Kinikar, M., 2013.

Machine Learning Algorithms for

Opinion Mining and Sentiment

Classification. International Journal of

Scientific and Research Publications,

June, 3(6), pp. 1-6.

[5] Liu, B., 2012. Sentiment Analysis and Opinion Mining. San Rafael: Morgan \& Claypool Publishers.

[6] Maning, C., Raghavan, P. \& Schutze, H., 2008. Introduction to Information

Retrieval. London: Cambridge University Press.

[7] Mitchell, T. M., 1997. Machine Learning. 1st ed. New York: McGrawHill.

[8] Pop, I., 2006. An approach of the Naive Bayes classifier for the document classification. General Mathematics, 14(4), p. 135-138.

[9] Routray, P., Swain, C. K. \& Mishra, S. P., 2013. A Survey on Sentiment Analysis. International Journal of Computer Applications, Agustus, 70(10), pp. 1-8.

[10] Taboada, M., Brooke, J., Tofiloski, M., Voll, K. \& Stede, M., 2011. LexiconBased Methods for Sentiment Analysis. Computational Linguistics, 37(2), pp. 267-307.

[11] Xhemali, D., J. Hinde, C. \& G. Stone, R., 2009. Naïve Bayes vs. Decision Trees vs. Neural Networks in the Classification of Training Web Pages. International Journal of Computer Science Issues, 4(1), pp. 16-23.

[12] Zhang, L., Ghosh, R., Dekhil, M., Hsu, M. \& Liu,B., 2011. Combining Lexiconbased and Learning-based Methods for Twitter Sentiment Analysis, Chicago: Hewlett-Packard Development Company, L.P. 